\title{
Screw Pullout Strength in Particleboards Manufactured with Waste of Eucalyptus grandis Wood Specie and Oat Hulls
}

\author{
Amós M. de Souza ${ }^{1}$, Luciano D. Varanda ${ }^{1}$, Fabiane S. Ferro ${ }^{1}$, André L. Christoforo ${ }^{2, *}$, \\ Felipe H. Icimoto ${ }^{1}$, Diego H. Almeida ${ }^{3}$, Francisco A. Rocco Lahr ${ }^{4}$ \\ ${ }^{1}$ Department of Materials Engineering, Engineering School of São Carlos (EESC/USP), São Carlos, 13566-590, Brazil \\ ${ }^{2}$ Centre for Innovation and Technology in Composites - CITeC, Department of Civil Engineering, Federal University of São Carlos, São \\ Carlos, 13565-905, Brazil \\ ${ }^{3}$ Pontifical Catholic University of Minas Gerais (PUC Minas), Department of Civil Engineering, Poços de Caldas Campus, Poços de Caldas, \\ 37701-355, Brazil \\ ${ }^{4}$ Department of Structural Engineering, Engineering School of São Carlos (EESC/USP), São Carlos, 13566-590, Brazil
}

\begin{abstract}
Eucalyptus wood species are usually found in rural constructions, civil construction, furniture and utensils, among other applications. The processing of Eucalyptus wood, which follows policies of reforestation in Brazil, generates a lot of waste, as the case of the oat hulls, which constitutes an aggravating to the environment, causing environmental impacts, which motivates the development of applications that make use of these residues, such as the case of particleboards. Among the mechanical properties commonly investigated in the characterization of the particleboards, there is the strength to screw pullout, which evaluates the bond strength of the manufactured materials. This research aimed to produce particleboards, in laboratory scale, using Eucalyptus grandis wood particles (proportions 0, 70, 85 e 100\%); oat hulls particles (proportions 0 , $14,30$ and $100 \%)$, both with controlled size distribution; castor oil based polyurethane resin $(10,12$ and $14 \%$, related to solid mass). These panels were evaluated concerning to pullout strength of screws (AP), from face and edge. Particle size distribution: 70 to $75 \%$ of these were found in interval ranging between 0.595 to $1.190 \mathrm{~mm}$ (16 to 30 mesh). Apparent density of Eucalyptus grandis and oat hulls were 0.64 and $0.29 \mathrm{~g} / \mathrm{cm}^{3}$, respectively. All panels were classified as high density (greater than $800 \mathrm{~kg} / \mathrm{m}^{3}$ ). Compression ratio of the panels showed range from 1.25 to 3.48 , remaining above the level usually recommended in literature (1.3 to 1.6), but similar to other related studies. Values of pullout strength of screws (face) met the requirements of Brazilian Standard ABNT NBR 14810:2006, for three of the twelve experimental conditions evaluated, and of pullout screw (edge), all panels met the cited requirements.
\end{abstract}

Keywords Particleboard, Strength to pullout, Eucalyptus wood specie

\section{Introduction}

Wood is a versatile, durable and renewable material, but has variations in their chemical, physical and anatomical compositions that can occur between species and within species. So some wood uses may be limited by dimensions, anisotropy and defects of the tree [1]. To minimize these limitations, wood based products, whose properties are significantly different from solid wood, emerged. Among these several kinds of panels can be mentioned, once show a interesting alternative to lumber for various applications [2].

Particleboard panels (now called medium density particleboards - MDP) were developed in Germany in the

* Corresponding author:

alchristoforo@yahoo.com.br (André L. Christoforo)

Published online at http://journal.sapub.org/cmaterials

Copyright (C) 2014 Scientific \& Academic Publishing. All Rights Reserved early 1940s. At the time, particleboards got importance due to the difficulty of obtaining compatible quality wood for plywood production, considering the isolation of Germany during World War II [3].

Iwakiri [3] defines particleboards as panels made of wood particles, incorporated with a synthetic adhesive, a random matrix reconstituted and consolidated by applying heat and pressure in the press hot.

Other lignocellulosic materials may also be used in the particleboards manufacturing, such as the industrial and agro-industrial residues. Currently, with the growing search for sustainable products, various researches are performed aiming at the recovery of wastes. Among then, those generated by agricultural industries presents great potential in the production of this kind of panel, as observed by Ciannamea [4] and Kwon [5].

In Brazil, agro-industrial residues are available in large volume and have significant potential for employment [6]. In 
particular, oat can be mentioned, once is usually consumed as food product in the country. Oat processing is responsible for generating a large volume of hulls, around $30 \%$ of the mass of oats [7]. This makes it feasible to evaluate their use, to add value to a material with potential environmental risk if not reused.

Looking at the expansion of the market of products based on wood and lignocellulosic particles, associated to the search for sustainable products, this study evaluates the possibility of production of particleboards from the reuse of waste and adopting, as adhesive, the so-called castor oil based polyurethane resin, partially natural and obtained from a renewable source.

The main objectives of this work were to produce particleboards, in laboratory scale [using Eucalyptus grandis and oat (Avena sativa) hulls particles, both with controlled size distribution and castor oil based polyurethane resin] and to evaluate their pullout strength of screws (AP), from face and edge. This parameter is fundamental to ensure good performance of the panels in several applications (furniture and building).

\section{Material and Methods}

This study was conducted at the University of São Paulo (USP), specifically in Wood and Timber Structures Laboratory (LaMEM), Department of Structural Engineering (SET), São Carlos Engineering School (EESC).

Residues of Eucalyptus grandis were obtained from companies in the region of São Carlos City, Brazil. Oat (Avena sativa) hulls were obtained from the industrial sector.

Castor-oil based polyurethane resin (PU) was employed as adhesive due to its high performance obtained in previous studies realized in LaMEM, with wood [8] and wood based products [9], [10] and [11].

The particles of Eucalyptus grandis and oat hulls presented average moisture content 7.9 and $10.3 \%$, respectively, compatible to the adopted resin. These particles were generated from the processing of waste in a knife mill, type Willye Marconi, model MA 680 , using a $2.8 \mathrm{~mm}$ sieve. Such dimensions were adopted once they already presented excellent performance in previous researches [8], [11] and [12]. Particle size analysis (Eucalyptus grandis and oat hulls) was carried out according to the specifications of ASTM corresponding to $7,10,16,30,40$ and 50 mesh.

In each panel, 640 grams of particles were bonded with the PU resin, used in proportions 10,12 and $14 \%$, related to mass of the particles. Mass of particles remained constant, so varying the compression ratio induces changes in panel density.

After complete homogenization of the particles with adhesive, the mixture was subjected to pre-pressing, to form the "mattress". The hot pressing of the panels was performed in semi - automatic equipment Marconi, model MA 098/50, with a capacity of $800 \mathrm{kN}$ and a maximum temperature of $200^{\circ} \mathrm{C}$
The pressing conditions used in this study were (a) time: ten minutes; (b) pressure: $4 \mathrm{MPa}$; (c) temperature: $100^{\circ} \mathrm{C}$. These parameters were subject to review by Dias [13] and Born [11], among several others.

Seventy two panels with nominal thickness $10 \mathrm{~mm}$ (commercially one of the most usual), and dimensions of $28 \times 28 \mathrm{~cm}$, determined in previous studies in LaMEM, were produced. After production, all panels were placed in a conditioned room, during seventy two hours, aiming to complete cure of the adhesive.

Density of panels was determined directly by the ratio mass/volume. Mass of the specimens was obtained on an electronic digital set Acatec model BDC-3300, sensitivity of 0.01 grams. To determine volume of specimens, a digital caliper Starrett, model 799, sensitivity of $0.01 \mathrm{~mm}$ was employed.

To determine the compression ratio, density adopted for Eucalyptus grandis was $640 \mathrm{~kg} / \mathrm{m}^{3}$, and for oat hulls 290 $\mathrm{kg} / \mathrm{m}^{3}$, according to data provided by the companies that publish such materials for this study.

ABNT NBR 14810 [15] doesn't establish requirements for APs (panels with thickness between 8 and 13mm). Usually for panels with nominal thicknesses less than $14 \mathrm{~mm}$, requirements for panels with thickness superior to $14 \mathrm{~mm}$ are adopted. Other researchers obtained satisfactory results regarding the APS (face/top) for all treatments considered [11] and [16].

Specimens of APs presented nominal dimensions $150 \mathrm{~mm} \times 75 \mathrm{~mm}$ (face) and $115 \mathrm{~mm} \times 65 \mathrm{~mm}$ (top), Figure 1 . Screw fixation in specimens was performed according to ABNT NBR 14810 [15]. The required force to screw pullout is held in the universal machine indicator, expressed in Newton (N). Each panel provided two specimens, one for APs face (Figure 1a) and one for top (Figure 1b).

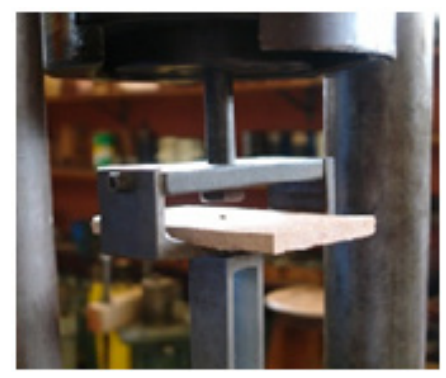

(a)

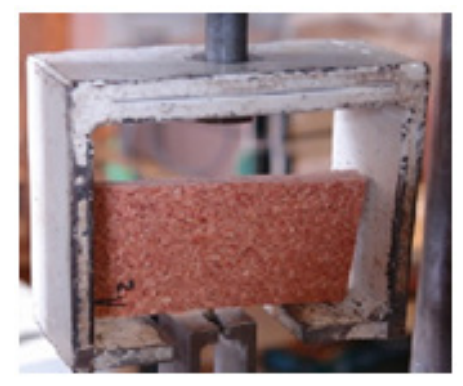

(b)

Figure 1. Pullout screw - face (a) and top (b) 
The produced particleboards were divided into groups, according to different proportions of particles of each material (Eucalyptus grandis and oat hulls). Table 1 shows the factors and levels used for planning experiments, resulting in twelve experimental conditions (CE), as presented in Table 2.

Table 1. Factors and experimental levels

\begin{tabular}{ccccc}
\hline Factors Input (\%) & \multicolumn{5}{c}{ Experimental levels } \\
\hline Eucalyptus grandis & 100 & 85 & 70 & 0 \\
Oat hulls & 0 & 15 & 30 & 100 \\
Adhesive & 10 & 12 & 14 & $\mathrm{X}$ \\
\hline
\end{tabular}

Table 2. Composition of factors

\begin{tabular}{cl}
\hline CE & \multicolumn{1}{c}{ Constituent proportions } \\
\hline 1 & $100 \%$ Eucalyptus grandis $-10 \%$ adhesive \\
2 & $100 \%$ Eucalyptus grandis $-12 \%$ adhesive \\
3 & $100 \%$ Eucalyptus grandis $-14 \%$ adhesive \\
4 & $(85 \%$ Eucalyptus grandis $-15 \%$ oat hulls $)-10 \%$ adhesive \\
5 & $(85 \%$ Eucalyptus grandis $-15 \%$ oat hulls $)-12 \%$ adhesive \\
6 & $(85 \%$ Eucalyptus grandis $-15 \%$ oat hulls $)-14 \%$ adhesive \\
7 & $(70 \%$ Eucalyptus grandis $-30 \%$ oat hulls $)-10 \%$ adhesive \\
8 & $(70 \%$ Eucalyptus grandis $-30 \%$ oat hulls $)-12 \%$ adhesive \\
9 & $(70 \%$ Eucalyptus grandis $-30 \%$ oat hulls $)-14 \%$ adhesive \\
10 & $100 \%$ oat hulls - $10 \%$ adhesive \\
11 & $100 \%$ oat hulls - 12\% adhesive \\
12 & $100 \%$ oat hulls - 14\% adhesive \\
\hline
\end{tabular}

Proportions pointed in Table 2 were adopted from preliminary experiments. For each of the twelve experimental conditions (EC) six panels were produced.

All data obtained in the tests were subjected to statistical analysis to assess if the factors and levels adopted in the experimental design (Table 1) have some influence on APs, at a confidence level of $95 \%$ [17]. Analysis of variance (ANOVA) using Minitab software, version 14, was carried out to investigate the influence of the combination of factors (Eucalyptus grandis, oat hulls and adhesive) on the response variables evaluated.

\section{Results and Discussions}

\section{Particle size analysis}

The particle size analysis was performed with the particles of Eucalyptus grandis and oat hulls by taking three samples of 200 grams for each material. Tables 3 and 4 present the average results obtained for the cited particles.

Analyzing the results shown in Tables 3 and 4, it can be observed there is a predominance of particle size between 0.595 and $1.190 \mathrm{~mm}$, or about $70 \%$ of the particles of Eucalyptus grandis and $75 \%$ of oat hulls present size in the mentioned range.

Weber [18] produced panels with particle sizes mostly in the range between 0.84 and $2.00 \mathrm{~mm}$ and obtained good physical and mechanical performance performance, despite using relatively larger particles compared to particles used in this study. Bertolini [8] used particles with particle sizes very similar to those employed here and got excellent physical and mechanical properties to her particleboards.

Table 3. Particle size distribution of Eucalyptus grandis

\begin{tabular}{cccc}
\hline $\begin{array}{c}\text { Sieve } \\
(\mathbf{m e s h})\end{array}$ & $\begin{array}{c}\text { Aperture } \\
\text { sieve }(\mathbf{m m})\end{array}$ & $\begin{array}{c}\text { Average of } \\
\text { retained mass } \\
\mathbf{( g )}\end{array}$ & $\begin{array}{c}\text { Average of } \\
\text { retained mass } \\
\mathbf{( \% )}\end{array}$ \\
\hline 7 & 2.830 & 0.6 & 0.3 \\
10 & 2.000 & 13.1 & 6.5 \\
16 & 1.190 & 66.7 & 33.4 \\
30 & 0.595 & 73.0 & 36.5 \\
40 & 0.420 & 17.6 & 8.8 \\
50 & 0.297 & 11.0 & 5.5 \\
Fine $<50$ & $<0.297$ & 18.0 & 9.0 \\
\hline Total & & 200.0 & 100.0 \\
\hline
\end{tabular}

Table 4. Particle size distribution of oat hulls

\begin{tabular}{cccc}
\hline $\begin{array}{c}\text { Sieve } \\
(\mathbf{m e s h})\end{array}$ & $\begin{array}{c}\text { Aperture } \\
\text { sieve }(\mathbf{m m})\end{array}$ & $\begin{array}{c}\text { Average of } \\
\text { retained mass } \\
\mathbf{( g )}\end{array}$ & $\begin{array}{c}\text { Average of } \\
\text { retained } \\
\text { mass (\%) }\end{array}$ \\
\hline 7 & 2.830 & 0.8 & 0.4 \\
10 & 2.000 & 13.4 & 6.7 \\
16 & 1.190 & 69.9 & 34.9 \\
30 & 0.595 & 80.7 & 40.4 \\
40 & 0.420 & 16.8 & 8.4 \\
50 & 0.297 & 7.4 & 3.7 \\
Fine $<50$ & $<0.297$ & 11.0 & 5.5 \\
\hline Total & & 200.0 & 100.0 \\
\hline
\end{tabular}

\section{Density and compression ratio}

Table 5 presents the average values of density and compression ratio for the twelve experimental conditions evaluated.

Table 5. Mean density (D) and right panels (RC) values

\begin{tabular}{ccccc}
\hline \multirow{2}{*}{$\mathbf{C E}$} & \multicolumn{2}{c}{ Density } & \multicolumn{2}{c}{ Compression ratio } \\
\cline { 2 - 5 } & $\mathbf{D ~ ( \mathbf { k g } / \mathbf { m } ^ { \mathbf { 3 } } )}$ & $\mathbf{C V} \mathbf{( \% )}$ & $\mathbf{R C}$ & $\mathbf{C V ~ ( \% )}$ \\
\hline 1 & 951 & 5.1 & 1.49 & 5.1 \\
2 & 957 & 5.5 & 1.50 & 5.5 \\
3 & 929 & 6.0 & 1.45 & 6.0 \\
4 & 941 & 6.9 & 1.60 & 6.9 \\
5 & 939 & 6.6 & 1.60 & 6.6 \\
6 & 927 & 9.5 & 1.58 & 9.5 \\
7 & 946 & 7.3 & 1.77 & 7.3 \\
8 & 913 & 9.2 & 1.71 & 9.2 \\
9 & 940 & 7.8 & 1.76 & 7.8 \\
10 & 1016 & 3.3 & 3.50 & 3.3 \\
11 & 968 & 6.0 & 3.34 & 6.0 \\
12 & 1008 & 4.8 & 3.48 & 4.8 \\
\hline
\end{tabular}

The coefficients of variation (CV) obtained for the density is below $10 \%$, which reflects the small variation of this property between panels evaluated. The coefficients of variation obtained are consistent with other studies [8], [16] 
and [18].

Variation in the density of the panels between the experimental conditions and from the same experimental condition was observed panels. This variation was also observed in other studies [19] and [20], and may be due to the production of the panels in the laboratory process, especially in the stages of assembly of the mattress and / or the addition of adhesives and other additives.

According Iwakiri [21], differences in the final density of the panel are attached to the material used in the manufacture of panels, the variables such as moisture content and particle density differences between the particles employed in the making of such panels.

In this study, the large variation in density of the panels $\left(800-1068 \mathrm{~kg} / \mathrm{m}^{3}\right.$, high density panels , is primarily related to two factors: the variables described the production process of the panels, and also the fact that fixed the total mass of particles in each panel 640 grams, varying the compression ratio and, consequently, the density of the panels.

As the compression ratio property, the coefficients of variation $(\mathrm{CV})$ obtained are less than $10 \%$, reflecting a slight variation of this property between panels. According Iwakiri (2005), the compression ratio for chipboard panels should be at least 1.3 for the densification necessary to the formation of the panel occurs. Maloney [22] and Moslemi [23] claimed that the compression ratio should be in the range from 1.3 to 1.6 to occur proper contact between the wood particles and formation of proper adhesive bond between them.

As seen in Table 5, the average values of the compression ratio stood at a range from 1.25 to 1.77 for the first nine experimental conditions. For them, the compression ratio is compatible with the established by Maloney [22] and Moslemi [23].

\section{Pullout of screws of top and face}

Table 6 shows the average values of the pullout strength of screws for the twelve experimental conditions evaluated.

Table 6. Mean values of the Fastener Pullout $\left(\mathrm{AP}_{\mathrm{s}}\right)$ of the panels

\begin{tabular}{ccccc}
\hline \multirow{2}{*}{$\mathbf{C E}$} & \multicolumn{2}{c}{ Face } & \multicolumn{2}{c}{ Top } \\
\cline { 2 - 5 } & $\mathbf{A P}_{\mathbf{f}} \mathbf{( N )}$ & $\mathbf{C V}(\mathbf{\%})$ & $\mathbf{A P}_{\mathbf{t}}(\mathbf{N})$ & $\mathbf{C V} \mathbf{( \% )}$ \\
\hline 1 & 892 & 40.8 & 1000 & 25.5 \\
2 & 1100 & 44.1 & 1558 & 35.1 \\
3 & 1200 & 21.7 & 2350 & 18.8 \\
4 & 908 & 35.7 & 958 & 33.4 \\
5 & 917 & 31.9 & 1075 & 30.7 \\
6 & 1083 & 32.2 & 1967 & 18.0 \\
7 & 650 & 38.0 & 950 & 34.3 \\
8 & 833 & 35.1 & 950 & 36.9 \\
9 & 1000 & 22.6 & 1758 & 30.9 \\
10 & 450 & 19.9 & 983 & 29.1 \\
11 & 692 & 25.2 & 1225 & 15.4 \\
12 & 742 & 28.1 & 1267 & 36.2 \\
\hline
\end{tabular}

Regarding the results of chunking Screw face $\left(\mathrm{AP}_{\mathrm{f}}\right)$, only the experimental conditions 2,3 and 6 (Table 6) met the requirements of ABNT NBR 14810 [15], which is $1020 \mathrm{~N}$ for panels with $14 \mathrm{~mm}$ thickness. These results are similar to those obtained by Weber [18] for this property, which fell in the range $810-1200 \mathrm{~N}$.

As for the strength of chunking Screw face $\left(\mathrm{AP}_{\mathrm{t}}\right)$, all our experimental conditions (Table 6) met the requirements of ABNT NBR 14810 [15], which are $800 \mathrm{~N}$ for panels with $14 \mathrm{~mm}$ thickness. For most of the evaluated test conditions, these results are better than those obtained by Weber [18] for this property located between $591-1346 \mathrm{~N}$. However, the results obtained by Bertolini [8], for this mechanical property, are superior to this study, with mean values among treatments $2496 \mathrm{~N}$.

\section{Statistical Analysis}

Table 7 presents the results of ANOVA for the mean pullout strength bolts face and top.

Table 7. P-values of the factors and interactions investigated in relation to screw pullout strength (AP)

\begin{tabular}{ccc}
\hline Experimental Factos & $\mathbf{A P}_{\mathbf{f}} \mathbf{( N )}$ & $\mathbf{A P}_{\mathbf{t}} \mathbf{( N )}$ \\
\hline Eucalyptus grandis & $\underline{0,000}$ & $\underline{0,002}$ \\
Adhesive & $\underline{0,006}$ & $\underline{0,000}$ \\
Oat hull & $\underline{0,000}$ & $\underline{0,002}$ \\
Eucalyptus grandis - Adhesive & 0,965 & $\underline{0,017}$ \\
Oat hull - Adhesive & 0,965 & $\underline{0,017}$ \\
\hline
\end{tabular}

The data relating to $\mathrm{AP}_{\mathrm{f}}$ were distributed uniformly along the straight, with regard to conditions of normality required for ANOVA model validation.

The $\mathrm{AP}_{\mathrm{f}}$ experimental values ranged between 300 and $1800 \mathrm{~N}$. The p-values $0.000,0.000$ and 0.006 underlined in Table 7 show that the experimental factors Eucalyptus grandis, oat hulls and adhesive, respectively, were significant.

Figure 2 shows the main effects of the experimental factors, it is observed that the strength of $\mathrm{AP}_{\mathrm{f}}$ is directly proportional to the increase in the percentage composition of Eucalyptus grandis and adhesive, with increases of 41 and $27.9 \%$, respectively, as presented in Figures $2 \mathrm{a}$ and $2 \mathrm{c}$.

The $\mathrm{AP}_{\mathrm{f}}$ is inversely proportional to the increase in the percentage composition of oat hulls, down $50.5 \%$ in value of the property (Figure $2 \mathrm{~b}$ ). The interactions of fractions of Eucalyptus grandis - adhesive and oat hulls - adhesive does not significantly affect the strength of $\mathrm{AP}_{\mathrm{f}}$ presented over 0.05 p-values (Table 7).

The data relating to $\mathrm{AP}_{\mathrm{f}}$ also distributed uniformly along the straight, with regard to conditions of normality required for ANOVA model validation.

The strength of $\mathrm{AP}_{\mathrm{f}}$ ranged between 400 and $3200 \mathrm{~N}$. The compositions of Eucalyptus grandis, oat hulls and adhesive were significant, showing p-values 0.002, 0.002 and 0.000 , respectively (Table 7). The strength of $\mathrm{AP}_{\mathrm{f}}$ decreased when adding the percentage composition of oat hulls, as shown in Figure 3b. However, the pullout strength increased proportionally to the compositions of Eucalyptus grandis 
and adhesive, with increases of 29.2 and $47 \%$, respectively, as shown in Figures 3a and 3c. The interactions of fractions of Eucalyptus grandis - adhesive and oat hulls were significant in $\mathrm{AP}_{\mathrm{f}}$, showing $\mathrm{p}$ - values lower than 0.05 (Table 7).

Analyzing the interactions shown in Figure 3, it is observed that the percentage composition of $14 \%$ of adhesive provided the greatest amount of force $\mathrm{AP}_{\mathrm{t}}$ both in interaction with Eucalyptus grandis and in interaction with oat hulls.

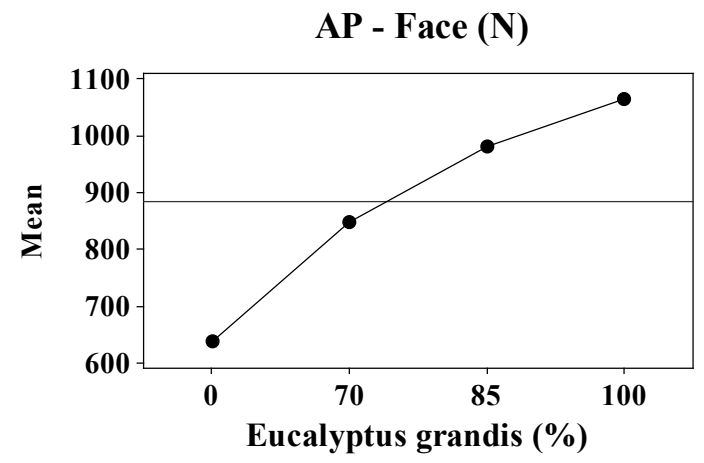

(a)

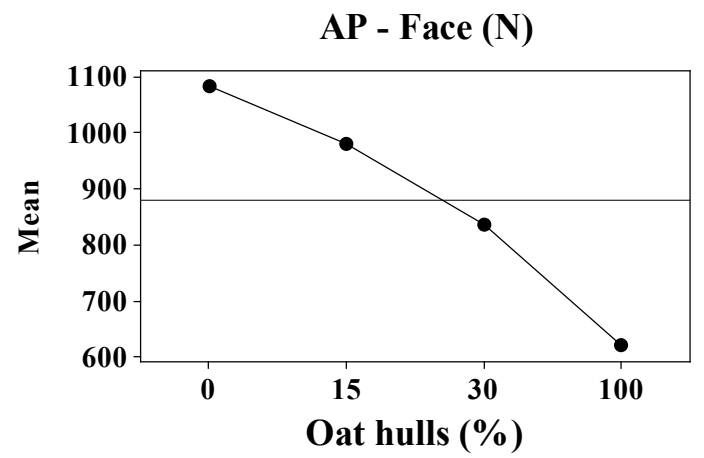

(b)

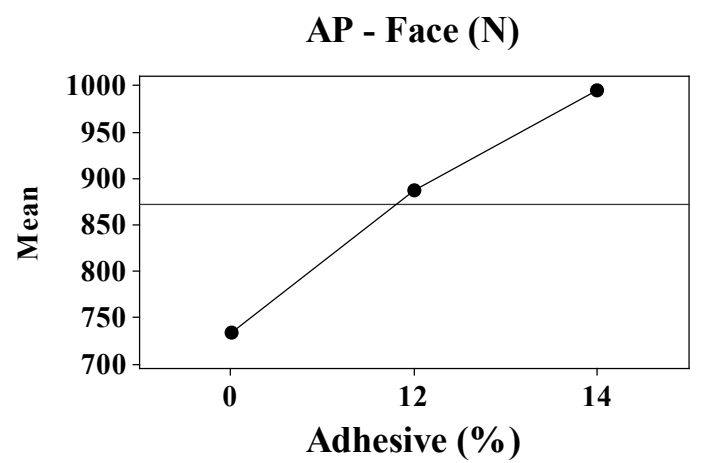

(c)

Figure 2. Main effect plot on the surface pullout of face. Fractions: Eucalyptus grandis (a), oat hulls (b) and adhesive (c)

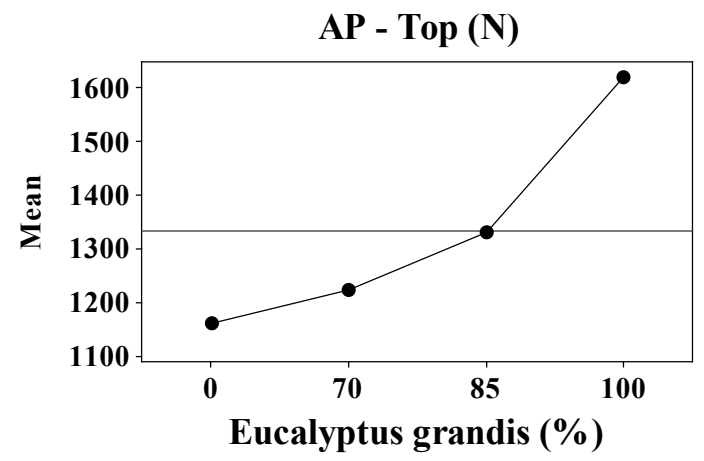

(a)

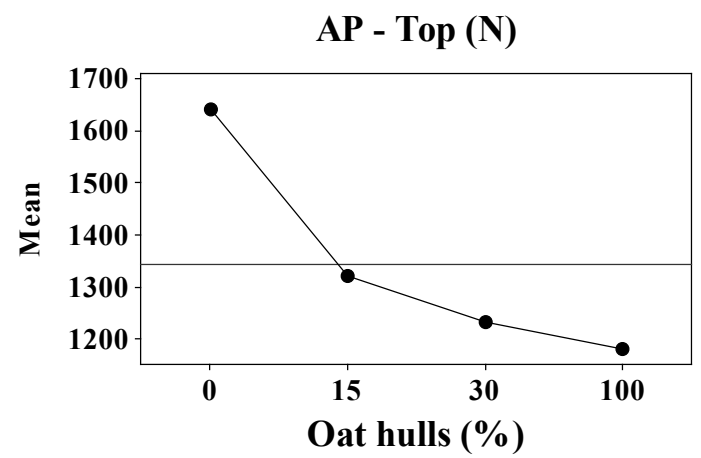

(b)

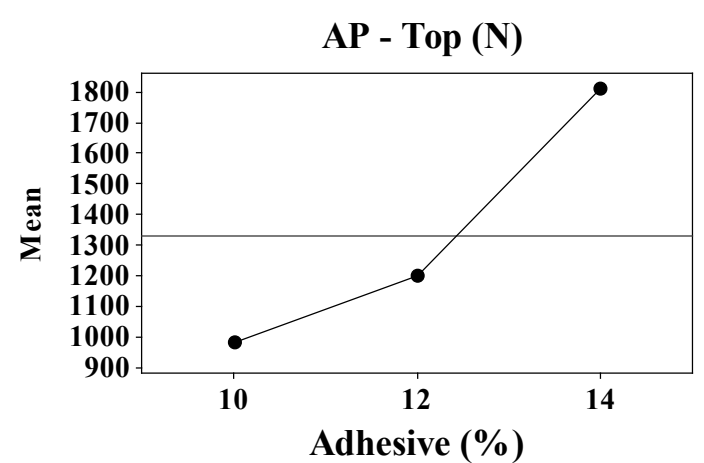

(c)

Figure 3. Main effects plot on the pullout screw on top. Fractions: Eucalyptus grandis (a), oat hulls (b) and adhesive (c)

\section{Conclusions}

As the particle size distribution, about $70-75 \%$ of these were found in the size range from 0.595 to $1.190 \mathrm{~mm}$ (16-30 mesh), consistent with other studies cited. The apparent density of the particles of Eucalyptus grandis and oat hulls were 0.64 and $0.29 \mathrm{~g} / \mathrm{cm}^{3}$, respectively;

All panels classified as high density (greater than 800 $\mathrm{kg} / \mathrm{m}^{3}$ ). The compression ratio of the panels showed great range in values ranging from 1.25 to 3.48 , remaining above 
the level recommended by the literature (1.30 to 1.60$)$, but similar to other studies mentioned;

The mechanical property of screw pullout face showed results that met the requirements of the Brazilian standard for three of the twelve experimental conditions evaluated. As for the mechanical property of screw pullout at the top, all panels met the requirements of the Brazilian standard.

\section{ACKNOWLEDGEMENTS}

The authors express their gratitude to CAPES and CNPq for granting scholarships and the Inter Science and Engineering of Materials Department, Wood and Timber Structures Laboratory, Structural Engineering Department, USP São Carlos that enabled the development of this research.

\section{REFERENCES}

[1] Feraboli P. Notched response of OSB wood composites, Compos Part A - Appl Sci, v. 39, p. 1355-1361, 2008.

[2] Rocco Lahr F. A. Produtos derivados da Madeira. In: Apresentação. (Org.), São Carlos: EESC-USP, 2008.

[3] Iwakiri, S. Produção de painéis aglomerados de alta densificação com uso de resina melamina-ureia-formaldeído. Cerne, Lavras, v. 11, n. 4, p. 323-328, 2005.

[4] Ciannamea E. M.; Stefani P. M.; Ruseckaite R. A. Medium-density particleboards from modified rice husks and soybean protein concentrate-based adhesives. Bioresource Technology, v.101, p.818-825, 2010.

[5] Kwon J. H.; Nadir Ayrilmis N.; Han T. H. Enhancement of flexural properties and dimensional stability of rice husk particleboard using wood strands in face layers. Composites: Part B, v. 44, p.728-732, 2013.

[6] Mendes R. F. Utilização do bagaço de cana de alambique na produção de painéis aglomerados. Monografia (Graduação), Universidade Federal de Lavras, Lavras. 104 p, 2008.

[7] Webster F. H. Oats chemistry and technology. Saint Paul: American Association of Cereal Chemists, 1986.

[8] Bertolini M. S. Emprego de resíduos de Pinus sp tratado com preservante $\mathrm{CCB}$ na produção de chapas de partículas homogêneas utilizando resina poliuretana à base de mamona. Dissertação (Mestrado), Escola de Engenharia de São Carlos, Instituto de Física de São Carlos, Instituto de Química de São Carlos da Universidade de São Paulo, São Carlos. 128 p, 2011.

[9] Campos C. I. Produção e caracterização de MDF a partir de fibras de madeira de reflorestamento e adesivos alternativos em diferentes teores. Tese (Doutorado), Escola de Engenharia de São Carlos, Instituto de Física de São Carlos, Instituto de Química de São Carlos da Universidade de São Paulo, São Carlos. 113 p, 2005.

[10] Dias F. M. Aplicação de resina poliuretana à base de mamona na fabricação de painéis de madeira compensada e aglomerada. 150 f. Tese (Doutorado), Escola de Engenharia de São Carlos, Instituto de Física de São Carlos, Instituto de Química de São Carlos da Universidade de São Paulo, São Carlos. 150p, 2005.

[11] Nascimento M. F. CHP - chapas de partículas homogêneas: madeiras do Nordeste do Brasil. Tese (Doutorado), Escola de Engenharia de São Carlos, Instituto de Física de São Carlos, Instituto de Química de São Carlos da Universidade de São Paulo, São Carlos. 143 p. 2003.

[12] Varanda L. D. Produção e avaliação do desempenho de painéis de partículas de Eucalyptus grandis confeccionados com adição de casca de aveia. Dissertação (Mestrado), Escola de Engenharia de São Carlos, Instituto de Física de São Carlos, Instituto de Química de São Carlos da Universidade de São Paulo, São Carlos. 155 p, 2012.

[13] Dias, F. M. Aplicação de resina poliuretana à base de mamona na fabricação de painéis de madeira compensada e aglomerada. Tese (Doutorado), Escola de Engenharia de São Carlos, Instituto de Física de São Carlos, Instituto de Química de São Carlos da Universidade de São Paulo, São Carlos. 150 p, 2005.

[14] Nogueira M. C. J. Indicações para o emprego de dezesseis Espécies de Eucalipto na Construção Civil. Dissertação (Mestrado), Escola de Engenharia de São Carlos, Instituto de Física de São Carlos, Instituto de Química de São Carlos da Universidade de São Paulo, São Carlos. 131 p, 1991.

[15] Associação Brasileira de Normas Técnicas ABNT NBR14810. Chapas de madeira aglomerada. Rio de Janeiro, 2006.

[16] Trianoski R. Avaliação do potencial de espécies florestais alternativas, de rápido crescimento, para produção de painéis de madeira aglomerada. Dissertação (Mestrado), Setor de Ciências Agrárias, Universidade Federal do Paraná, Curitiba. 260 p, 2010.

[17] Montgomery D. C. Design and analysis of experiments. 6. ed. Arizona: John Wiley \& Sons Inc, 2005.

[18] Weber C. Estudo sobre viabilidade de uso de resíduos de compensados, MDF e MDP para produção de painéis aglomerados. Dissertação (Mestrado) - Setor de Ciências Agrárias, Universidade Federal do Paraná, Curitiba. 87p, 2011.

[19] Dacosta L. P. E. et al. Qualidade das chapas de partículas aglomeradas fabricadas com resíduos do processamento mecânico da madeira de Pinus elliottii Engelm. Ciência Florestal, Santa Maria, v. 15, n. 03, p. 311-322, 2005.

[20] Melo R. R. et al. Propriedades físico-mecânicas de painéis aglomerados produzidos com diferentes proporções de madeira e casca de arroz. Ciência Florestal, Santa Maria, v. 19, n. 4, p. 449-460, 2009.

[21] Iwakiri S. A influência das variáveis de processamento sobre propriedades das chapas de partículas de diferentes espécies de Pinus. Tese (Doutorado), Setor de Ciências Agrárias, Universidade Federal do Paraná, Curitiba. 130p, 1989.

[22] Maloney T. M. modern particleboard and dry-process fiberboard. San Fancisco: miller freeman, 1993.

[23] Moslemi A. A. particleboard. London: Southern Illinois University Press, 1974. 